\title{
MEDIA PEMBELAJARAN DARING MENGGUNAKAN METODE DEMONSTRASI PADA MATA PELAJARAN GEOGRAFI UNTUK MEMBERI EDUKASI TENTANG KAWASAN TANAH GAMBUT DI SMAN 10 PETUK KATIMPUN
}

\author{
Rinto Alexandro ${ }^{1}$, Ahmad Frenky Okada ${ }^{2}$, Elisabet Pardosi ${ }^{3}$, Jeni Makaruehni ${ }^{4}$, Amita Sari ${ }^{5}$, \\ Antoni $^{6}$, Indah Cici Lestari $\mathbf{J}^{7}$, Jonlika ${ }^{8}$, Nur Istiqomah ${ }^{9}$, Pandi Irawandi ${ }^{10}$, Sayu Hartini ${ }^{11}$, Selvi ${ }^{12}$, \\ Septiana $^{13}$, Yenasadieni ${ }^{14}$, Yunus Labora ${ }^{15}$, Yunyanti Suryani ${ }^{16}$ \\ Program Studi Pendidikan Ekonomi, Universitas Palangka Raya \\ *Email: rinto.alexandro@fkip.upr.ac.id
}

\begin{abstract}
ABSTRAK
Lahan gambut terbentuk karena adanya penambahan bahan organik segar yang lebih cepat dari pada perombakannya sehingga terjadi timbunan organic dari waktu ke waktu gambut Indobesia sangat potensial di manfaatkan untuk penyediaan bahan pangan. Pemanfaatan lahan gambut yang lebih masif untuk memasok bahan pangan di picu oleh (1) laju alih fungsi lahan pertanian, (2) pertambahan jumlah penduduk, dan (3) keinginan menjadikan Indonesia sebagai lumbung pangan dunia. Tanah gambut dalam system klasifikasi tanah USDA termasuk dalam ordo Histosol. Tanah gambut juga dapat di klasifikasikan berdasarkan tingkat dekomposisi, kesuburan, fisiografi, proses pembentukan, bahan penyusun dan ketebalan gambut. Berdasarkan ketebalan gambut, tanah gambut dengan ketebalan 50-100 cm di kategori dalam gambut dangkal atau tipis. Karakteristik dan potensi lahan gambut di tentukan oleh sifat kimia, fisika, dan biologi. Semakin tebal gambut, semakin rendah potensi untuk budidaya tanaman dan hortikultura. Potensi lahan gambut dangkal atau tipis di Indonesia di perkirakan sekitar 5 juta 241.473 ha atau 35,17\% dari total luas lahan gambut Indonesia, tersebar di pulau Papua ( 2.425 .523 ha), pulau Sumatra (1.767.303 ha), dan pulau Kalimantan (1.048.611 ha). Lahan tersebut baru sebagian kecil dimanfaatkan petani untuk budidaya tanaman pangan, dan hortikultura dengan produktifitas yang tergolong rendah. Kebakatan lahan gambut dan factor lainnya menyebakan terjadinya dinamika luas lahan gambut tipis. Potensi gambut tipis dapat dimanfaatkan untuk budidaya tanaman pangan seperti padi, jagung, dan kedelai, tanaman hortikultura buah-buahan seperti nenas, pisang, papaya, melon,dan tamanaman hortikultura sayuran berupa tomat, pare, mentimun, cabai, kangkong, dan bayam. Kontribusi lahan gambut tipis terhadap produksi tanaman pangan dan hortikultura di perkirakan 50-60\% dari tital produksi lahan gambut.
\end{abstract}

Kata Kunci: Media Pembelajaran Daring, Metode Demonstrasi, Mata Pelajaran Geografi

\section{ONLINE LEARNING MEDIA USING DEMONSTRATION METHOD IN GEOGRAPHIC LESSONS TO GIVE EDUCATION ABOUT PEAT AREA IN SMAN 10 KATIMPUN}

\begin{abstract}
Peatlands are formed due to the addition of fresh organic material which is faster than the overhaul so that organic pile occurs from time to time. Indonesian peat is very potential to be utilized for food supply. The more massive use of peatlands to supply food is triggered by (1) the rate of conversion of agricultural land, (2) population growth, and (3) the desire to make Indonesia a world food barn. Peat soil in the USDA soil classification system is included in the Histosol order. Peat soils can also be classified based on the level of decomposition, fertility, physiography, formation process, constituent material and peat thickness. Based on peat thickness, peat soil with a thickness of 50$100 \mathrm{~cm}$ is categorized in shallow or thin peat. The characteristics and potential of peatlands are determined by chemical, physical, and biological properties. The thicker the peat, the lower the potential for crop cultivation and horticulture. The potential of shallow or thin peatlands in Indonesia is estimated to be around 5 million 241,473 ha or $35.17 \%$ of the total area of Indonesia's peatlands, spread over Papua (2,425,523 ha), Sumatra (1,767,303 ha), and Kalimantan $(1,048,611$ ha). Only a small part of the land is used by farmers for food crop cultivation, and
\end{abstract}


BAKTI BANUA : Jurnal Pengabdian Kepada Masyarakat

Volume 1 No. 2 November 2020

e-ISSN : 2722-3736

p-ISSN : 2722-7529

https:/ / ejurnal.stimi-bjm.ac.id/index.php/BBJM/

horticulture with relatively low productivity. Peatlands and other factors cause the dynamics of thin peatlands. Potential of thin peat can be utilized for the cultivation of food crops such as rice, corn, and soybeans, fruit horticultural crops such as pineapple, banana, papaya, melon, and vegetable horticultural gardens such as tomatoes, bitter melons, cucumbers, cucumbers, chillies, and spinach. The contribution of peatlands to the production of food and horticulture is thin, it is estimated that $50-60 \%$ of the peatland production is carried out.

Keywords: Online Learning Media, Demonstration Method, Subjects Geography

\section{PENDAHULUAN}

Pendidikan Tinggi yang diselenggarakan di Perguruan Tinggi (PT) pada dasarnya merupakan amanat UUD 1945 dalam UU RI No. 2 tahun 1989 dan Sistem Pendidikan Nasional Juncto Peraturan Pemerintah RI/No./60/1999 tentang pendidikan tinggi. Perguruan Tinggi sebagai lembaga pendidikan hendaknya mampu membekali dan mengembangkan religiusitas, kecakapan, keterampilan, kepekaan dan kecintaan mahasiswa terhadap pemuliaan kehidupan umat manusia pada umumnya dan masyarakat Indonesia pada khususnya. Universitas Palangka Raya (UPR) sebagai salah satu perguruan tinggi di indonesia senantiasa melaksanakan ketiga aspek dalam tridharma perguruan tinggi dalam proporsi yang seimbang, harmonis, dan terpadu. Salah saatu wujud pengalaman tridarma perguruan tinggi bidang pengabdian masyarakat di Universitas Palangka Raya pelaksanaan Kuliah Kerja Nyata Tematik (KKN-T). Melalui surat keputusan rektor Universitas palangka Raya no. 338/H24/LL/2010 tanggal 3 juni 2010, kuliah kerja nyata mahasiswa (K2NM) ditetapkan sebagai kegiatan yang wajib diikuti setiap mahasiswa program strata satu (S-1) dari semua jurusan/program studi di Universitas Palangka Raya. Kuliah Kerja Nyata Tematik (KKN-T) Universitas Palangka Raya yang sebelumnya dikenal dengan Kuliah Kerja Nyata Mahasiswa (K2NM). Namun sejak periode I tahun 2017 diubah namanya menjadi Kuliah Kerja Nyata Pembelajaran Dan Pemberdayaan Masyarakat (KKN-T) guna menyamakan kegiatan KKN-T di Universitas Palangka Raya dengan Perguruan Tinggi lainnya di Indonesia. KKN-T adalah suatu bentuk pendidikan dengan cara memberikan pengalaman belajar kepada mahasiswa untuk hidup ditengah-tengah masyarakat di luar kampus, dengan secara lansung mengidentifikasi serta menangani masalah-masalaah pembangunan yang kontekstual dalam masyarakat dengan pelibatan secara langsung masyarakat didalam merencanakan dan pelaksanaan program kerjanya yang berbasiskan hasil penelitian. KKN-T Adalah bagian integral dari proses pendidikan yang mempunyai ciri khusus. Karena sistem penyelenggaraan serta pengertian landasan ideal secara filosofi gambaran serta pengertian yang utuh tentang apa, bagaimana, serta untuk apa diselenggarakan sehingga dapat memberikan petunjuk serta mengendalikan pola pikir, pola sikap dan pola tindak dalam setiap proses penyelenggaraannya. KKN-T sekurang-kurangnya mengandung 7 aspek yang bernilai fundamental dan berwawasan filosofi, yang tidak dapat dipisahkan antara satu dengan yang lainnya yaitu keterpaduan pelaksanaan tridharma Perguruan Tinggi, pelestarian tri gatra KKN-T. Pendekatan interdisipliner dan komprehensif, lintas sektoral, dimensi yang luas realistis dan pragmatis, keterlibatan masyarakat secara aktif, serta pengembangan lingkungan. Keputusan KKN-T periode I tahun 2020 Universitas Palangka Raya dengan topik Kesatuan Hidrologis Gambut Kalimantan Tengah, kelompok kami (A9) menggunakan metode "Demonstrasi", Pembahasan utama dalam pembelajaran ini adalah IPS yang menyangkut bagaimana pengembangan dan sosialisasi pengetahuan yang berhubungan dengan Biofisik Ekosistem Tanah Gambut, yang dilakukan secara Online atau Via Daring dengan lingkup sman 10 Petuk Ketimpun Palangka Raya.

Pengabdian ini mengambil tema tentang media pembelajaran daring, kemudian menggunakan metode demonstrasi untuk menyampaikan materi tentang kawasan hutan gambut ini. dikarenakan kami melihat situasi saat ini yaitu sedang terjadi pandemik covid 2019. Kita semua tahu bahwa kondisi pendidikan di negeri kita saat ini banyak berubah, semua sekolah yang ada di indonesia ini di anjurkan oleh pemerintah melakukan proses belajar-mengajar melalui media pembelajaran daring. Oleh karena itu kami belum menemukan hasil-hasil penelitian pendukung untuk penelitian ini. Tetapi ada banyak artikel saat ini yang menuliskan tentang gambaran kondisi pendidikan di indonesia saat ini, salah satunya adalah yang di bawah ini. "Sebagaimana kita lihat hampir semua orangtua di Indonesia pada saat ini, tanggung 
BAKTI BANUA : Jurnal Pengabdian Kepada Masyarakat

Volume 1 No. 2 November 2020

e-ISSN : 2722-3736

p-ISSN : 2722-7529

https://ejurnal.stimi-bjm.ac.id/index.php/BBJM/

jawab mendampingi anak mereka belajar dari rumah. Banyak orangtua harus mengakui bahwa menjelaskan berbagai mata pelajaran dan menemani anak-anak mengerjakan tugas-tugas sekolah tidak semudah yang dibayangkan.Kerja keras para guru dan dosen selama ini sungguh patut diapresiasi. Di tengah pembatasan sosial akibat wabah covid-19, kita harus tetap semangat mengejar dan mengajar ilmu pengetahuan. Hampir tidak ada yang menyangka, wajah pendidikan akan berubah drastis akibat pandemi covid19. Konsep sekolah di rumah (home-schooling) tidak pernah menjadi arus utama dalam wacana pendidikan nasional. Meski makin populer, penerapan pembelajaran online (online learning) selama ini juga terbatas pada Universitas Terbuka, program kuliah bagi karyawan di sejumlah universitas dan kursuskursus tambahan (online courses).Tapi, kebijakan physical distancing untuk memutus penyebaran wabah, memaksa perubahan dari pendidikan formal di bangku sekolah menjadi belajar dari rumah, dengan sistem online, dalam skala nasional. Bahkan, ujian nasional tahun ini terpaksa ditiadakan. Tantangan pendidikanSistem pendidikan online pun tidak mudah. Di samping disiplin pribadi untuk belajar secara mandiri, ada fasilitas dan sumber daya yang mesti disediakan.Saya bersyukur masih mampu memfasilitasi anak kami untuk pendidikan jarak jauh, tapi saya mendengar keluhan banyak orangtua murid dan juga tenaga pendidik yang kesulitan, baik dalam menyediakan perangkat belajar seperti ponsel dan laptop maupun pulsa untuk koneksi internet.Dengan kata lain, sistem pembelajaran online ini berpotensi membuat kesenjangan sosial ekonomi yang selama ini terjadi, menjadi makin melebar saat pandemi. Kemenaker (20/4) mencatat sudah lebih dari 2 juta buruh dan pekerja formal-informal yang dirumahkan atau diPHK. Dengan kondisi seperti ini, banyak orangtua kesulitan menyediakan kesempatan pendidikan yang optimal bagi anak-anak mereka.Dalam situasi yang lebih buruk, orangtua malah bisa berhadapan pada pilihan dilematis: memberi makan keluarga atau membiayai pendidikan anak. Ini berpotensi membuat angka putus sekolah meningkat. Sejak kebijakan belajar dari rumah diterapkan secara nasional mulai tanggal 16 Maret 2020, muncul indikasi naiknya angka putus sekolah di berbagai tempat. Mulai dari Papua, Maluku Utara, hingga Jakarta. Ini daerah-daerah yang tergolong zona merah dalam penyebaran wabah. Angka putus sekolah dari kawasan perdesaan juga diperkirakan akan naik. Dalam jangka panjang, anak-anak yang putus sekolah ini memiliki kemungkinan lebih besar untuk menganggur, baik secara tertutup atau terbuka. Ini bukan hanya secara akumulatif akan menurunkan produktivitas nasional, tapi membuat mereka terjebak da- mereka terjebak dalam lingkaran tidak berujung (vicious circle) kemiskinan struktural.Sebagai langkah solusi praktis, sejak awal saya berpendapat pemerintah perlu merealokasikan dana pelatihan Rp5,6 triliun bagi 5,6 juta buruh dan pekerja yang diperkirakan terdampak krisis ekonomi akibat wabah covid-19, menjadi bantuan langsung. Sehingga, bisa digunakan untuk memenuhi kebutuhan sehari-hari.Termasuk, memastikan keberlangsungan pendidikan anak-anak mereka. Di sisi lain, pemerintah juga perlu memperhatikan juga perlu memperhatikan nasib para guru, terutama guru-guru swasta maupun guru honorer (termasuk guru tidak tetap), yang masingmasing berjumlah hampir satu juta orang. Ketiadaan proses belajar mengajar di sekolah, secara langsung dan tidak langsung, menurunkan pendapatan mereka. Pendidikan adalah kunci”

\section{METODE}

Metode penelitian adalah langkah yang dimiliki dan dilakukan oleh peneliti dalam rangka untuk mengumpulkan informasi atau data serta melakukan investigasi pada data yang telah didapatkan tersebut. Metode penelitian memberikan gambaran rancangan penelitian yang meliputi antara lain: prosedur dan langkah-langkah yang harus ditempuh, waktu penelitian, sumber data, dan dengan langkah apa data-data tersebut diperoleh dan selanjutnya diolah dan dianalisis. Metode penelitian ini terbagi ke beberapa bagian yaitu:

Metode observasi (pengamatan).

Pengamatan adalah alat pengumpulan data yang dilakukan dengan cara mengamati dan mencatat secara sistimatik gejala-gejala yang ada di SMA Negeri 10 Palangka Raya, Pada metode pegamatan ini, penulis terjun langsung untuk mengamati secara langsung terhadap pelaksanaan KKN, kegiatan-kegiatan dan fenomena-fenomena sosial yang terjadi sebagai dampak dari pelaksanaan KKN yang diterapkan. Data 
BAKTI BANUA : Jurnal Pengabdian Kepada Masyarakat

Volume 1 No. 2 November 2020

e-ISSN : 2722-3736

p-ISSN : 2722-7529

https://ejurnal.stimi-bjm.ac.id/index.php/BBJM/

yang diperlukan dalam metode pengamatan ini adalah, mengamati secara langsung dilokasi, pelaksanaan proses, kegiatan-kegiatan program mahasiswa Universitas Palangka Raya di SMA Negeri 10 Palangka Raya.

Metode Interview

Metode ini disebut juga dengan metode wawancara, yaitu suatu metode pengumpulan data yang dilakukan melalui Tanya jawab secara langsung dengan sumber data. Interview merupakan alat pengumpulan informasi dengan cara mengajukan pertanyaan secara lisan, untuk dijawab secara lisan juga, ciri utama dari interview adalah kontak langsung dengan tatap muka antara pencari informasi dengan sumber informasi, Dalam wawancara secara mendalam ini dilakukan oleh peneliti terhadap informan yang menjadi obyek dari penelitian ini yaitu Kepala sekolah dan guru di SMA Negeri 10 Palangka Raya, Wawancara ini bertujuan untuk memeperoleh informasi yang ada relevansinya dengan pokok persoalan penelitian yaitu kerja sama mahasiswa dengan Kepala sekolah beserta guru-guru di SMA Negeri 10 Palangka raya.

Metode Dokumentasi

Dalam penelitian kualitatif terdapat sumber data yang berasal dari bukan manusia seperti dokumen foto-foto, dan bahan statistic. Metode dokumentasi ini merupakan salah satu bentuk pengumpulan data yang paling mudah, karena peneliti hanya mengamati benda mati dan apabila mengalami kekeliruan mudah untuk merevisinya karena sumber datanya tetap dan tidak berubah. Dokumen yang diperlukan dalam penelitian ini meliputi KHG tersebut, dan sarana yang dimiliki oleh SMA Negeri 10 Palangka Raya, dan data-data lain yang dibutuhkan untuk melengkapi penyusunan laporan ini : Data-data yang di lengkapi dalam penelitian seperti :

\section{Alat dan Bahan yang Digunakan}

Untuk jalannya penelitian memerlukan alat dan bahan untuk mempermudah pengerjaan penelitian dan juga implementasi aplikasi.

1. Alat Alat yang di pergunakan seperti perangkat keras dan juga perangkat lunak.

a. Perangkat Keras

> Komputer dan laptop 32/64 bit architecture processor, 8 GB Random Access Memmory RAM, sistem Operasi windows 8,

Handphone, dan

$>$ Printer dokumen untuk mencetak laporan.

b. Perangkat Lunak

$>$ Adobe photoshop 2016

c. Bahan Bahan yang di gunakan selama penelitian yaitu:

a) Data yang di dapatkan melalui user dalam penelitian yang masih mempunyai keterkaitan dengan aplikasi yang di kembangkan dari data yang di peroleh, maka dari itu kebutuhan yang ada bisa membuat kebutuhan yang di peruntukan untuk aplikasi saat pembuatan video, dan

b) Data admin Sekolah.

\section{HASIL DAN PEMBAHASAN}

Kami mengambil tema tentang media pembelajaran daring, kemudian menggunakan metode demonstrasi untuk menyampaikan materi tentang kawasan hutan gambut ini. dikarenakan kami melihat situasi saat ini yaitu sedang terjadi pandemik covid 2019. Kita semua tahu bahwa kondisi pendidikan di negeri kita saat ini banyak berubah, semua sekolah yang ada di indonesia ini di anjurkan oleh pemerintah melakukan proses belajar-mengajar melalui media pembelajaran daring. Oleh karena itu kami belum menemukan hasil-hasil penelitian pendukung untuk penelitian ini. Tetapi ada banyak artikel saat ini yang menuliskan tentang gambaran kondisi pendidikan di indonesia saat ini, salah satunya adalah yang di bawah ini. Sebagaimana kita lihat hampir semua orangtua di Indonesia pada saat ini, tanggung jawab mendampingi anak mereka belajar dari rumah. Banyak orangtua harus mengakui bahwa menjelaskan berbagai mata pelajaran dan menemani anak-anak mengerjakan tugas-tugas sekolah tidak semudah yang 
BAKTI BANUA : Jurnal Pengabdian Kepada Masyarakat

Volume 1 No. 2 November 2020

e-ISSN : 2722-3736

p-ISSN : 2722-7529

https://ejurnal.stimi-bjm.ac.id/index.php/BBJM/

dibayangkan.Kerja keras para guru dan dosen selama ini sungguh patut diapresiasi. Di tengah pembatasan sosial akibat wabah covid-19, kita harus tetap semangat mengejar dan mengajar ilmu pengetahuan. Hampir tidak ada yang menyangka, wajah pendidikan akan berubah drastis akibat pandemi covid19. Konsep sekolah di rumah (home-schooling) tidak pernah menjadi arus utama dalam wacana pendidikan nasional. Meski makin populer, penerapan pembelajaran online (online learning) selama ini juga terbatas pada Universitas Terbuka, program kuliah bagi karyawan di sejumlah universitas dan kursuskursus tambahan (online courses).Tapi, kebijakan physical distancing untuk memutus penyebaran wabah, memaksa perubahan dari pendidikan formal di bangku sekolah menjadi belajar dari rumah, dengan sistem online, dalam skala nasional. Bahkan, ujian nasional tahun ini terpaksa ditiadakan. Tantangan pendidikanSistem pendidikan online pun tidak mudah. Di samping disiplin pribadi untuk belajar secara mandiri, ada fasilitas dan sumber daya yang mesti disediakan. Saya bersyukur masih mampu memfasilitasi anak kami untuk pendidikan jarak jauh, tapi saya mendengar keluhan banyak orangtua murid dan juga tenaga pendidik yang kesulitan, baik dalam menyediakan perangkat belajar seperti ponsel dan laptop maupun pulsa untuk koneksi internet.Dengan kata lain, sistem pembelajaran online ini berpotensi membuat kesenjangan sosial ekonomi yang selama ini terjadi, menjadi makin melebar saat pandemi. Kemenaker (20/4) mencatat sudah lebih dari 2 juta buruh dan pekerja formal-informal yang dirumahkan atau di PHK. Dengan kondisi seperti ini, banyak orangtua kesulitan menyediakan kesempatan pendidikan yang optimal bagi anak-anak mereka.Dalam situasi yang lebih buruk, orangtua malah bisa berhadapan pada pilihan dilematis: memberi makan keluarga atau membiayai pendidikan anak. Ini berpotensi membuat angka putus sekolah meningkat. Sejak kebijakan belajar dari rumah diterapkan secara nasional mulai tanggal 16 Maret 2020, muncul indikasi naiknya angka putus sekolah di berbagai tempat. Mulai dari Papua, Maluku Utara, hingga Jakarta. Ini daerah-daerah yang tergolong zona merah dalam penyebaran wabah. Angka putus sekolah dari kawasan perdesaan juga diperkirakan akan naik. Dalam jangka panjang, anak-anak yang putus sekolah ini memiliki kemungkinan lebih besar untuk menganggur, baik secara tertutup atau terbuka. Ini bukan hanya secara akumulatif akan menurunkan produktivitas nasional, tapi membuat mereka terjebak da- mereka terjebak dalam lingkaran tidak berujung (vicious circle) kemiskinan struktural.Sebagai langkah solusi praktis, sejak awal saya berpendapat pemerintah perlu merealokasikan dana pelatihan Rp5,6 triliun bagi 5,6 juta buruh dan pekerja yang diperkirakan terdampak krisis ekonomi akibat wabah covid-19, menjadi bantuan langsung. Sehingga, bisa digunakan untuk memenuhi kebutuhan sehari-hari.Termasuk, memastikan keberlangsungan pendidikan anak-anak mereka. Di sisi lain, pemerintah juga perlu memperhatikan juga perlu memperhatikan nasib para guru, terutama guru-guru swasta maupun guru honorer (termasuk guru tidak tetap), yang masingmasing berjumlah hampir satu juta orang. Ketiadaan proses belajar mengajar di sekolah, secara langsung dan tidak langsung, menurunkan pendapatan mereka. Pendidikan adalah kunci”.

Hasil dari energi yang diolah dan diklarisifikasikan menjadi keluaran yang berguna dan sisa pembuangan.

1) Hasil Kuantitatif

Terselesaikannya program KKN daring di SMA Negeri 10 Palangka Raya, pada waktu yang ditentukan oleh pihak sekolah itu sendiri.

2) Hasil Kualitatif

Dengan progam KKN daring di SMA Negeri 10 Palangka Raya, anggota KKN memberikan bahan ajar berupa video tentang edukasi pemanfaatan tanah gambut.

\section{PEMBAHASAN}

1. Pengertian Lahan Gambut

Lahan adalah suatu sumber daya dalam suatu wilayah dalam bentuk daratan yang di dalamnya mencakup semua karakteristik yang berperan dalam pembentukan lahan tersebut serta lingkungannya. Gambut adalah bahan organik tumbuhan yang menumpuk pada kondisi reduksi. Lama waktu penumpukan tidak sebanding yaitu lebih cepat dari pada waktu pengurainnya sehingga bahan organik 
BAKTI BANUA : Jurnal Pengabdian Kepada Masyarakat

Volume 1 No. 2 November 2020

e-ISSN : 2722-3736

p-ISSN : 2722-7529

https://ejurnal.stimi-bjm.ac.id/index.php/BBJM/

tersebut tidak mengalami dekomposisi secara sempurna.Lahan gambut adalah sebidang lahan yang lapisan tanahnya tersusun oleh bahan organik yang banyak kandungan karbon organiknya $18 \%$ dan tebalnya mencapai hingga lebih dari $50 \mathrm{~cm}$ (Agus dan Subiksa 2008). Sesuai dengan namanya, lahan ini merupakan lahan yang tanahnya dipenuhi dengan gambut.

2. Bertani Secara Bijak

Bertani di lahan gambut memang harus dilakukan secara hati-hati karena menghadapi banyak kendala antara lain kematangan dan ketebalan gambut yang bervariasi, penurunan permukaan gambut, rendahnya daya tumpu, rendahnya kesuburan tanah, adanya lapisan pirit dan pasir, $\mathrm{pH}$ tanah yang sangat masam, kondisi lahan gambut yang jenuh air (tergenang) pada musim hujan dan kekeringan saat kemarau, serta rawan kebakaran.

Kunci keberhasilan pertanian di lahan gambut adalah bertani secara bijak dengan memperhatikan faktor-faktor pembatas yang dimilikinya. Ada 10 langkah bijak agar sukses bertani di lahan gambut, yaitu :

a. Mengenali dan memahami tipe dan perilaku lahan;

b. Memanfaatkan dan menata lahan sesuai dengan tipologinya dengan tidak merubah lingkungan secara drastis;

c. Menerapkan sistem tata air yang dapat menjamin kelembaban tanah/menghindari kekeringan di musim kemarau dan mencegah banjir di musim hujan;

d. Tidak melakukan pembukaan lahan dengan cara bakar;

e. Bertani secara terpadu dengan mengkombinasikan tanaman semusim dan tanaman tahunan, ternak, dan ikan;

f. Memilih jenis dan varietas tanaman yang sesuai dengan kondisi lahan dan permintaan pasar;

g. Menggunakan bahan amelioran seperti kompos dan pupuk kandang untuk memperbaiki kualitas lahan;

h. Mengolah tanah secara minimum (minimum tillage) dalam kondisi tanah yang berair atau lembab;

i. Menggunakan pupuk mikro bagi budi daya tanaman semusim;

j. Melakukan penanaman tanaman tahunan di lahan gambut tebal didahului dengan pemadatan dan penanaman tanaman semusim untuk meningkatkan daya dukung tanah.

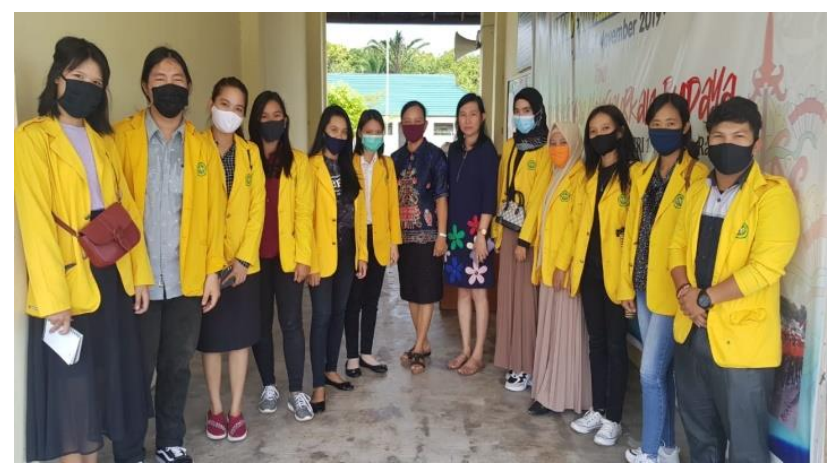

Gambar 1. Foto Bersama Guru SMAN 10 Petuk Ketimpun Palangka Raya 
BAKTI BANUA : Jurnal Pengabdian Kepada Masyarakat

Volume 1 No. 2 November 2020

e-ISSN : 2722-3736

p-ISSN : 2722-7529

https://ejurnal.stimi-bjm.ac.id/index.php/BBJM/

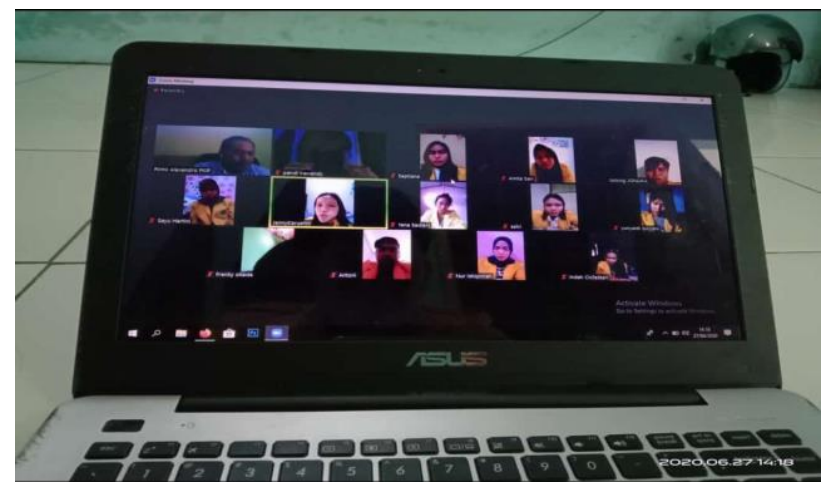

Gambar 2. Foto Paparan kegiatan Online Kelompok Bersama DPL

3. Evaluasi Kegiatan

a. pada hari pertama dan kedua kami memulai dengan melakukan pengenalan lokasi sekolah terlebih dahulu,untuk melihat dan menyusun program kerja apa yang dapat dikerjakan di sekolah tersebut sesuai dengan kondisi ruanglingkup sekolah tersebut.

b. Pada hari selanjutnya kami melakukan pengambilan dan melakukan sedikit wawancara kepada pihak sekolah untuk mengetahui apakah rancangan program kerja yang kami susun dapat diterima dan meminta sedikit usulan dari pihak sekolah tentang apa yang ingin dibuat di lingkungan sekolah tersebut.

c. Selajutnya, setelah program kerja tersusun dan di setujui oleh pihak sekolah kami langsung memulai program pertama pada tanggal 4-5 juni 2020 yaitu membuat protokol kesehatan covid 19 (bilik sterilisasi) pada lorong sekolah untuk melakukan kegitan penerimaan peserta didik secara offline.

d. Selajutnya, kami melanjutkan salah satu program kami yaitu pembuatan taman di SMA Negeri 10 Palangka Raya, untuk mengurangi kerindangan sekolah dan memperindah ruanglingkup sekolah. Kemudian kami juga melakukan penanaman tanaman hidroponik karena dapat dikelola oleh manusia secara khusus dan kondisi lingkungan terkontrol.

e. Selanjutnya, kegiatan yang kami lakukan adalah membantu penerimaan peserta didik baru secara offline, kami juga melakukan pembersihan ruangan sebelum digunakan untuk menerima siswa/siswi yang ingin melakukan pendaftaran secara offline.

f. Selanjutnya, kami melakukan kegiatan pembuatan kolam ikan yang di lakukan dengan menggali tanah dan pemasangan terpal. Selanjutnya kami melakukan pengisian air kolam dan pemasukan bibit ikan patin sebanyak 100 ekor.

g. Kegiatan yang terakhir yang kami lakukan adalah pembuatan video bahan ajar yang di buat oleh anggota kelompok dengan materi yang berkaitan dengan KHG.

\section{SIMPULAN}

Sejak awal perencanaan kegiatan KKN-T ini memang di laksanakan secara daring, dalam rangka mengikuti protokol kesehatan untuk menghindari dan mencegah penularan covid-19 yang sedang menjadi pandemik saat ini, oleh karena itu kami mengambil judul yaitu "Media Pembelajaran Daring Menggunakan Metode Demonstrasi Pada Mata Pelajaran Ips (Geografi) Untuk Memberi Edukasi Tentang Kawasan Tanah Gambut (Khg) Di Sman 10 Petuk Katimpun Palangka Raya". Tetapi untuk dapat menyelesaikan KKN-T ini ada banyak hal yang harus kami hadapi di lapangan untuk memperoleh data dan semua yang kami perlukan, seperti harus terjun langsung kelapangan. Awalnya kami kelompok A9 telah merancang sebuah program yang ingin diberikan di sekolah tersebut, dan program ini berupa " media bahan belajar dalam bentuk video " yang dimana program tersebut berbentuk video bahan ajar yang dimana untuk menunjang proses belajar mengajar secara daring akibat pandemi Covid - 19 yang telah 
BAKTI BANUA : Jurnal Pengabdian Kepada Masyarakat

Volume 1 No. 2 November 2020

e-ISSN : 2722-3736

p-ISSN : 2722-7529

https://ejurnal.stimi-bjm.ac.id/index.php/BBJM/

melanda Palangka Raya sejak 3 Bulan yang lalu. Kemudian setelah kami datang dan melihat kondisi di lapangan. Ada permasalahan yang kami temukan pada pengangkatan judul, dikarenakan kalender akademik menyatakan bahwa tanggal 1 - 28 juni 2020 merupakan jadwal ulangan akhir semester (UAS), penyusunan laporan dan penerimanaan peserta didik baru. Sehingga pengakatan judul ini tidak dapat diterapan secara langsung, melainkan menunggu tahun ajaran baru dimulai.

Meskipun kami mengalami banyak kesulitan dalam menyesuaikan program awal kami dengan kondisi yang ada di lapangan, kami akhirnya tetap berhasil menyelesaikan tugas kami dengan sukses, yaitu:

1. Membuat bilik strealisasi untuk Protokol Covid-19

Kegiatan ini dilaksakanan pada minggu pertama tanggal 4-5 juni 2020 ,yang diselenggarakan di SMAN 10 Palangka Raya, yang dimana protokol ini dapat digunakan untuk pencengahan penularan covid-19 yang dilakukan untuk para peserta didik baru yang melakukan pendaftaran offline.

2. Pembuatan Taman

Kegiatan ini dilaksanakan pada minggu kedua tanggal 8-10 juni 2020 , kegiatan ini berupa penanaman bibit bunga serta obat-obat herbal di sekitar lingkungan sekolah SMAN 10 Palangka Raya. Program ini dilakukan karena kondisi lingkungan sekolah yang masih gersang maka kami beinisiatif untuk menanam tanaman bunga dan obat-obatan herbal, agar semakin sejuk udara dan sekitar sekolah. Hal ini karena tanaman memproduksi oksingen dan mempercantik lingkungan.

3. Tanaman Hidroponik

Kegiatan ini di laksanakan pada minggu kedua tanggal 11-12 juni 2020, kegiatan ini juga berupa tanaman hidroponik dengan bahan yang digunakan pipa 3 inci, kain panel, dan palastik paranel, rookkwool serta bibit sawi, seledri dan bayam. Selain itu juga tanaman sayur ini bisa sekaligus dijadikan tanaman hias di sekitar sekolah. Dengan begitu, selain bermanfaat untuk di konsumsi sayuran hidroponik bisa dijadikan salah satu alternatif pengganti tanaman hias.

4. Membuat Kolam Ikan

Kegiatan ini dilaksanakan pada minggu kedua dan minggu ketiga tanggal 18-23 2020, kegiatan ini berupa pembuatan kolam, yang dimana kami melihat di sekolah tersebut cocok untuk membudidayakan ikan, oleh karena itu sangat besar manfaatnya baik bagi siswa maupun sekolah dan jikadi kembangkan secara serius itu bisa menjadi dana tambahan dan menunjang fasilitas yang ada di sekolah.

5. Membuat Media Pembelajaran Daring

Kegiatan ini dilaksanakan pada minggu ke empat tanggal 24-28 juni 2020, kegiatan ini dilakukan dengan pembuatan video bahan ajar pemanfaatan lahan gambut untuk memberikan wawasan kepada peserta didik agar peserta didik dapat memahami pentingnya pemanfaatan lahan gambut di sekolah SMAN 10 Palangka Raya.

Sehingga apa yang ingin kami sampaikan dari kegiatan KKN-T ini kepada baik kami sebagai mahasiswa, sekolah, terlebih-lebih lagi masyarakat, dapat kami capai dengan baik. Dan kami berharap apa yang sudah kami berikan dalam pelaksanaan KKN-T ini dapat bermanfaat terutama dalam hal edukasi tentang pemanfaatan kawasan lahan gambut ini meskipun harus melalui sekolah dan siswa.

\section{UCAPAN TERIMAKASIH}

\section{Assalaamu'alaikum warahmatullaahi wabarakatuh}

Alham dulillahirabbil'alamiin, puji syukur kehadirat Allah SWT yang telah memberikan hidayah, kesempatan dan kemudahan kepada kita semua dalam menjalankan amanah yang menjadi tanggung jawab kita. Shalawat serta salam selalu tercurah kepada junjungan kita Nabi Muhammad SAW, beserta keluarga dan para sahabat, karena dengan syafa'atnya kita dapat hijrah dari zaman jahiliyah menuju zaman yang terang benderang. Atas karunia dan pertolongan dari Allah SWT, program Kuliah Kerja Nyata (KKN-T) 
BAKTI BANUA : Jurnal Pengabdian Kepada Masyarakat

Volume 1 No. 2 November 2020

e-ISSN : 2722-3736

p-ISSN : 2722-7529

https://ejurnal.stimi-bjm.ac.id/index.php/BBJM/

Periode I di kota Palangka Raya, Kecamatan Jekan Raya, Provinsi Kalimantan Tengah yang dimulai sejak tanggal 28 Mie 2020 sampai dengan tanggal 7 Juli 2020 dapat berjalan dengan lancar dan dapat terselesaikan dengan baik hingga dengan tersusunnya laporan akhir ini. Laporan ini disusun sebagai salah satu penilaian dari seluruh program Kuliah Kerja Nyata serta untuk mengetahui sejauh mana program kegiatan mahasiswa dalam melaksanakan KKN-T dapat terealisasi dengan baik. Dengan tujuan untuk melakukan pengabdian kepada masyarakat, kami berharap semoga seluruh program KKN-T yang telah berjalan dapat bermanfaat bagi kedua belah pihak. Kami menyadari bahwa pelaksanaan Kuliah Kerja Nyata dan penyusunan laporan ini tidak lepas dari bimbingan, dorongan dan bantuan baik materi maupun non materi dari berbagai pihak, sehingga program-program yang telah direncanakan dapat terealisasi dengan baik dan dapat diselesaikan dengan tepat waktu. Oleh karena itu perkenankanlah kami menghaturkan ucapan terimakasih kepada:

1. Bapak Rektor Universitas Palangka Raya Bapak Dr. Andrie Elia, S. E.,M.Si yang telah memberikan kesempatan kepada penulis untuk melaksanakan program Kuliah Kerja Nyata.

2. Ayah dan Ibu, terimakasih atas do'anya karena dengan do'a itu bisa membentangkan sayap jutaan malaikat untuk melindungi setiap langkah kami.

3. Bapak Dr. Rinto Alexandro,SE.,MM selaku Dosen Pembimbing Lapangan atas bimbingan dan pengarahan yang telah diberikan.

4. Bapak Drs. H. Kaprawi, M.Pd selaku kepala sekolah.

5. Badan Pelaksana Kuliah Kerja Nyata Universitas Palangka Raya

6. Bapak Rektor Universitas Palangka Raya Bapak Dr. Andrie Elia, S. E.,M.Si yang telah memberikan kesempatan kepada penulis untuk melaksanakan program Kuliah Kerja Nyata.

7. Pihak sekolah, terimakasih banyak atas segala bantuan dan kerjasamanya sehingga Kuliah Kerja Nyata ini dapat berjalan dengan lancar.

Semua pihak yang sudah berpartisipasi dan memberi dukungan baik materi maupun non materi yang tidak dapat penulis sebutkan satu persatu. Semoga segala bantuan, bimbingan dan pengajaran yang telah diberikan kepada kami mendapatkan imbalan dari Allah SWT. Tidak lupa kami mohon maaf apabila selama melaksanakan tugas KKN-T terdapat kekhilafan dan kesalahan. Kami menyadari sepenuhnya akan keterbatasan kemampuan yang kami miliki. Oleh karena itu, kami mengharapkan adanya kritik dan saran yang membangun demi kesempurnaan naskah publikasi kami. Akhirnya, semoga dengan adanya pembuatan naskah publikasih ini dapat bermanfaat bagi semua yang membaca dan membutuhkannya.

Wassalaamu'alaikum warahmatullaahi wabarakatuh

\section{DAFTAR PUSTAKA}

http://media.neliti.com/media/publications/189506-ID-pengaruh-amelioran-formulasi-terhadap-ku.pdf. Di akses pada tanggal 17 Juni 2020

http://www.menlhk.go.id/site/single_post/2085. Di akses pada tanggal 17 Juni 2020

http://jurnalsosekpu.pu.go.id/index.php/sosekpu/article/view/143

https://id.wikipedia.org/wiki/Gambut

https://www.menlhk.go.id/site/single_post/2085

$\underline{\text { https://rimbakita.com/lahan-gambut/ }}$

https://rimbakita.com/lahan-gambut/

http://webblogkkn.unsyiah.ac.id/papeun9/ucapan-terima-kasih/ 